\title{
Threonine 32 (Thr32) of FoxO3 is critical for TGF- $\beta$-induced apoptosis via Bim in hepatocarcinoma cells
}

\author{
Xiangxuan Zhao ${ }^{1,2,3 \bowtie}$, Yong $\mathrm{Liu}^{1,2}$, Lei $\mathrm{Du}^{1,2}$, Leya $\mathrm{He}^{4}$, Biyun $\mathrm{Ni}^{1,2}$, Junbo $\mathrm{Hu}^{4}$, Dahai Zhu ${ }^{5}$, Quan $\mathrm{Chen}^{1,2,6 \bowtie}$ \\ ${ }^{1}$ The Joint Laboratory of Apoptosis and Cancer Biology, The State Key Laboratory of Biomembrane and Membrane \\ Biotechnology, Institute of Zoology, Chinese Academy of Sciences, Beijing 100101, China \\ ${ }^{2}$ University of Chinese Academy of Sciences, Beijing 100049, China \\ 3 Department of Radiology, Shengjing Hospital of China Medical University, Shenyang 110004, China \\ ${ }^{4}$ Cancer Research Center, Tongji Hospital, Tongji Medical College, Huazhong University of Science and Technology, Wuhan \\ 430032, China \\ ${ }^{5}$ Institute of Basic Medical Sciences of Chinese Academy of Medical Sciences and School of Basic Medicine of Peking Union \\ Medical College, Beijing 100005, China \\ ${ }^{6}$ College of Life Science, Nankai University, Tianjin 300071, China \\ $\triangle$ Correspondence: zhaoxiangxuan@gmail.com (X. Zhao), chenquan@nankai.edu.cn (Q. Chen)
}

Received September 1, 2014 Accepted October 30, 2014

\begin{abstract}
Transforming growth factor- $\beta$ (TGF- $\beta$ ) exerts apoptotic effects on various types of malignant cells, including liver cancer cells. However, the precise mechanisms by which TGF- $\beta$ induces apoptosis remain poorly known. In the present study, we have showed that threonine 32 (Thr32) residue of $\mathrm{FoxO} 3$ is critical for TGF- $\beta$ to induce apoptosis via Bim in hepatocarcinoma Hep3B cells. Our data demonstrated that TGF- $\beta$ induced FoxO3 activation through specific de-phosphorylation at Thr32. TGF- $\beta$-activated FoxO3 cooperated with Smad2/ 3 to mediate Bim up-regulation and apoptosis. FoxO3 (de)phosphorylation at Thr32 was regulated by casein kinase I- $\varepsilon$ (CKI- $\varepsilon)$. CKI inhibition by small molecule D4476 could abrogate TGF- $\beta$-induced FoxO/Smad activation, reverse $\mathrm{Bim}$ up-regulation, and block the sequential apoptosis. More importantly, the deregulated levels of $\mathrm{CKI}-\varepsilon$ and $\mathrm{p} 32 \mathrm{FoxO} 3$ were found in human malignant liver tissues. Taken together, our findings suggest that there might be a CKI-FoxO/Smad-Bim engine in which Thr32 of FoxO3 is pivotal for TGF- $\beta$ induced apoptosis, making it a potential therapeutic target for liver cancer treatment.
\end{abstract}

KEYWORDS apoptosis, TGF- $\beta$, FoxO3, casein kinase $\mathrm{I}-\varepsilon$, hepatocarcinoma

\section{INTRODUCTION}

TGF- $\beta$ mainly signals through activating a heteromeric receptor complex consisting of type I (TGF-RI) and type II (TGF-RII) serine/threonine kinase on the cell membrane (Massague and Weis-Garcia, 1996). The activated TGF- $\beta$ receptors phosphorylate downstream adaptor proteins such as Smad2 and Smad3. Receptor-activated Smads are associated with a common Smad4 and translocate to the nucleus to modulate TGF- $\beta$ target genes (Derynck and Zhang, 2003; Enroth et al., 2014; Engel et al., 1998; Massague et al., 2005). Increasing evidence indicated that Smad proteins cooperate with a variety of transcription factors, including AP-1, TFE3 and FoxO to activate gene transcription or repress gene expression in association with oncoproteins such as Evi-1, E1A, Ski, SnoN, Tid1 and Akt (Hua et al., 1998; Remy et al., 2004; Runyan et al., 2012; Torregroza and Evans, 2006; Vignais, 2000; Yamamura et al., 2000; Seoane et al., 2002). TGF- $\beta$ can induce apoptosis in malignant cells through up-regulating of pro-apoptotic proteins such as Bim and Bmf, or down-regulating anti-apoptotic proteins such as Bcl-xL (Nass et al., 1996; Ramjaun et al., 2007).

The FoxO transcription factor family, including FoxO1, FoxO3 and FoxO4 is reported to act as potent transcription activators and tumor suppressors. Specifically, FoxO3 is phosphorylated by a couple of protein kinases such as $\mathrm{PKB} /$ Akt and CKI (Conery et al., 2004; Waddell et al., 2004). Once 
phosphorylated, FoxO3 is sequestrated in the cytoplasm and its ability to activate transcription of target genes is inhibited. It has been reported that TGF- $\beta$ induces $\mathrm{FoxO} 3$ to actively engage with Smads to result in cell cycle arrest by up-regulating p27 (Park et al., 2013; Kato et al., 2006). Studies also showed that TGF- $\beta$ enhances FoxO3 phosphorylation and down-regulates Bim expression to inhibit apoptosis in mesangial cells (Naka et al., 2010). However, the roles of FoxO3 in TGF- $\beta$-induced apoptosis in liver cancer cells have yet to be fully elucidated.

Casein kinase I (CKI) family proteins consisting of seven isoforms $(\alpha, \beta, \gamma 1-3, \delta$ and $\varepsilon$ ) can phosphorylate $p 53$ or $\beta$-catenin to regulate their activity; Of note, $\mathrm{CKI}-\varepsilon$ is regarded as a constitutively active kinase and its activity is regulated by (auto) phosphorylation status (Fish et al., 1995; Tuazon and Traugh, 1991; Knippschild et al., 2005; Graves et al., 1993). Previous studies reported that CKI- $\varepsilon$ can enhance TGF- $\beta$-induced Smad-mediated gene transcription (Renard et al., 2008; Miyazono, 2000). Currently, the mechanism by which $\mathrm{CKI}-\varepsilon$ regulates FoxO3 activity to affect TGF- $\beta$-induced apoptosis remains unclear.

The present study sought to study the roles of $\mathrm{FoxO} 3$ in TGF- $\beta$-induced apoptosis using in vitro cell models. We proved that TGF- $\beta$ triggers apoptosis via Bim elevation in Hep3B cells. TGF- $\beta$ activated FoxO3 by dephosphorylation at $\mathrm{Thr} 32$ and the activated FoxO3 functionally cooperated with $S$ mad2/3 to mediate Bim up-regulation. CKI- $\varepsilon$ regulated FoxO3 activity by Thr32 phosphorylation site and affected TGF- $\beta$-induced Bim up-regulation and apoptosis. Deregulated expression of $\mathrm{CKI}-\varepsilon$ and $\mathrm{p} 32 \mathrm{FoxO} 3$ was observed in malignant liver tissues. Our findings suggest that a $\mathrm{CKI}-\varepsilon-$ FoxO3/Smad-Bim engine could be considered as a potential target to treat liver cancer.

\section{RESULTS}

TGF- $\beta$ induces Bim-dependent apoptosis in Hep3B cells

To evaluate the apoptotic effects of TGF- $\beta$, Hep3B cells were treated with TGF- $\beta$. Apoptosis was determined by FACS analysis based on Annexin V-PI double staining, caspase-3 cleavage activation and cytochrome $c$ release from mitochondria. We observed significant apoptosis in TGF- $\beta$-treated cells (Fig. 1A-C). Regarding Bcl-2 family proteins are essential regulators of cytochrome $c$ release from mitochondria (Green and Reed, 1998), next we analyzed the expression of Bcl-2 family proteins in Hep3B cells treated with TGF- $\beta$. We found that Bim was significantly up-regulated at both protein and mRNA levels, while Bax and Bcl-xL were not apparently affected (Fig. 1D and 1E). To further verify the roles of Bim in Hep3B cells treated with TGF- $\beta$, immunofluorescence staining assays were performed. Our data showed that Bim was elevated and translocated to mitochondria in cells treated with TGF- $\beta$ (Fig. 1F), suggesting Bim may play key roles in cytochrome $c$ release from mitochondria. To validate whether TGF- $\beta$-induced apoptosis is Bim dependent, we used the
Figure 1. TGF- $\beta$ induces Bim dependent apoptosis in Hep3B cells. (A) TGF- $\beta$-induced apoptosis in Hep3B cells. Cells treated with TGF- $\beta$ ( $5 \mathrm{ng} / \mathrm{mL}$ ) for up to $48 \mathrm{~h}$ were harvested and processed for apoptotic assay by using the Annexin V-PI double staining as described in 'METHODS AND MATERIALS'. Statistical analysis was carried out to assess the ratio of apoptosis. Representative data were shown and every experiment was repeated three times ( $\left.{ }^{\star} P<0.05\right)$. (B) Detection of apoptosis by caspase- 3 activation. Cells treated as in Fig. $1 \mathrm{~A}$ were harvested and cell lysates were prepared for Western blotting analysis to detect levels of cleaved caspase- 3 with specific antibody recognizing cleaved caspase-3. $\beta$-Actin protein levels were assessed as loading controls for equal total protein amounts. Representative immuno-bands were shown and every experiment was repeated three times. (C) Cytochrome $c$ release from mitochondria. Cells cultured on glass cover slips were treated with TGF- $\beta(5 \mathrm{ng} / \mathrm{mL})$ for $48 \mathrm{~h}$ or not (Control). Fluorescence immunostaining was performed to detect cytochrome $\mathrm{c}$ with anti-cytochrome $\mathrm{c}$ primary mouse antibody. Bound cytochrome c was labeled with FITC conjugated goat anti-mouse secondary antibody (green). Mitochondria were stained with Mito-Tracker (Red). (D) TGF- $\beta$-induced Bim up-regulation at protein level. Cells incubated in the absence or presence of TGF- $\beta$ for up to $720 \mathrm{~min}$ were harvested and cell lysates were prepared for Western blotting to detect levels of Bim, Bax and Bcl-xL with antibodies specifically recognizing $\mathrm{Bim}, \mathrm{Bax}$ and $\mathrm{Bcl}-\mathrm{xL}$ respectively. $\beta$-Actin protein levels were assessed as loading controls for equal total protein amounts. Relative band intensities (RBIs) were analyzed by the Image $\mathrm{J}$ software. (E) TGF- $\beta$-induced Bim up-regulation at mRNA level. Cells were treated as in $D$ and semi-quantitative RT-PCR was used to detect levels of Bim, Bax and Bcl-xL mRNA. GAPDH mRNA were assessed and set up as equal loading control. Relative band intensities (RBIs) were analyzed by the Image $\mathrm{J}$ software. (F) Bim up-regulation and translocation. Cells cultured on cover slips were treated for up to $48 \mathrm{~h}$ or not. Immunofluorescence staining was performed as described in 'MATERIALS AND METHODS'. Bim was recognized with anti-Bim rabbit $\mathrm{pAb}$ and bound Bim primary antibody was labeled with FITC conjugated goat anti-rabbit IgG (Green). Mitochondria were stained with Mito-Tracker (Red). (G) TGF- $\beta$-induced Bim-dependent apoptosis. Cells cultured in six-well plate were transfected with synthesized scramble control siRNA and Bim specific siRNA, and $48 \mathrm{~h}$ post-transfection, cells were treated with TGF- $\beta(5 \mathrm{ng} / \mathrm{mL})$ for $48 \mathrm{~h}$ or not. Bim expression and apoptotic effects based on caspase- 3 cleavage activation were determined through Western blotting. $(H)$ Cells cultured in six-well plate were transfected with synthesized scramble control siRNA and Bim specific siRNA, and $48 \mathrm{~h}$ post-transfection, cells were treated with TGF- $\beta$ ( $5 \mathrm{ng} / \mathrm{mL}$ ) for $48 \mathrm{~h}$ or not. Apoptotic ratio was determined by counting cells with apoptotic nuclei as described in 'MATERIALS AND METHODS'. Data represent the mean values of three independent experiments $\left({ }^{*} P<0.05\right)$. 


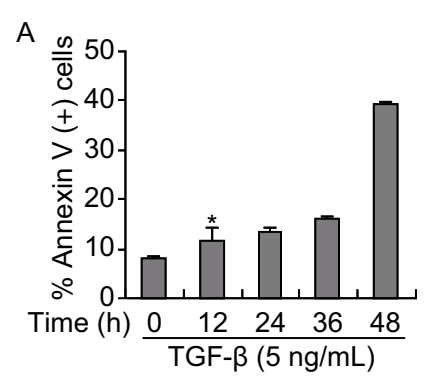

D
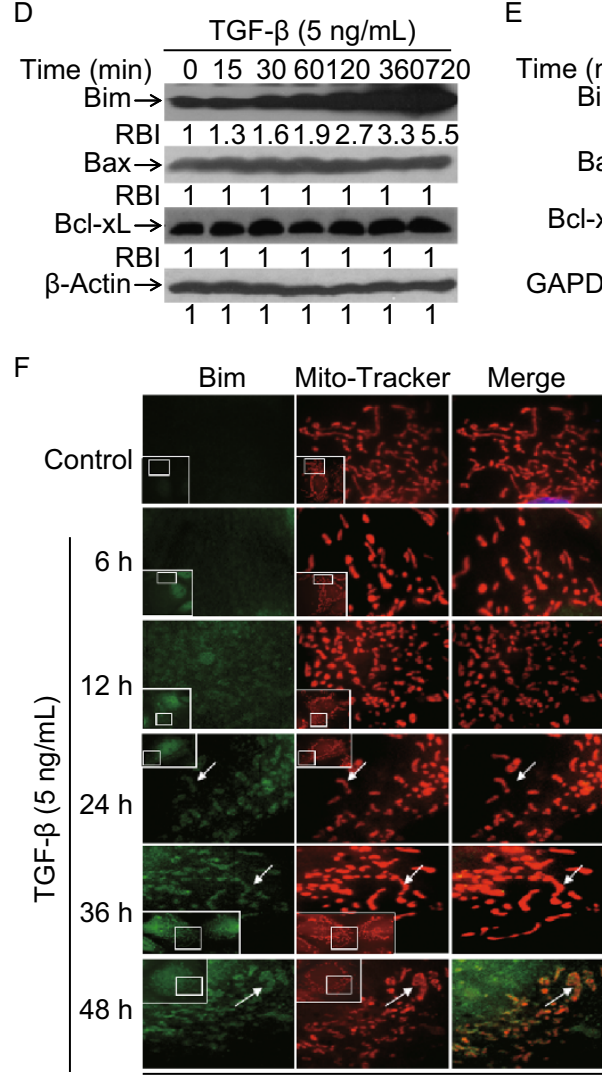

(Bim: green; mitochondria: red; magnification : 400x)
B

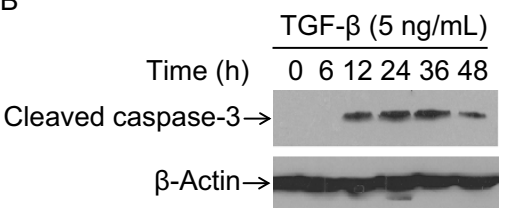

E Time (min) $\frac{\text { TGF- } \beta(5 \mathrm{ng} / \mathrm{mL})}{0153060120360720}$ $\mathrm{Bim} \rightarrow$ RBI 1 1.21.71.82.12.42.5 $\mathrm{Bax} \rightarrow-\infty-\infty-\infty$

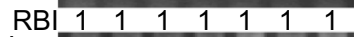
$\mathrm{BCl}-\mathrm{xL} \rightarrow \longrightarrow \mathrm{CO}$

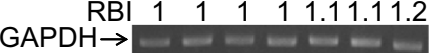

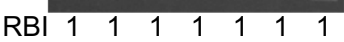
G

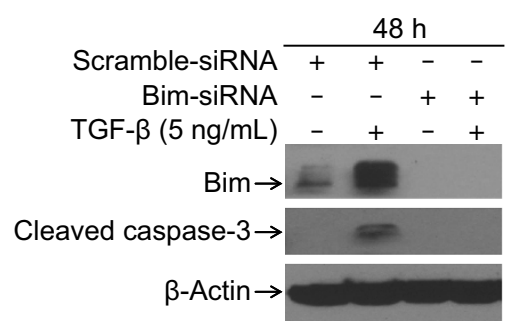

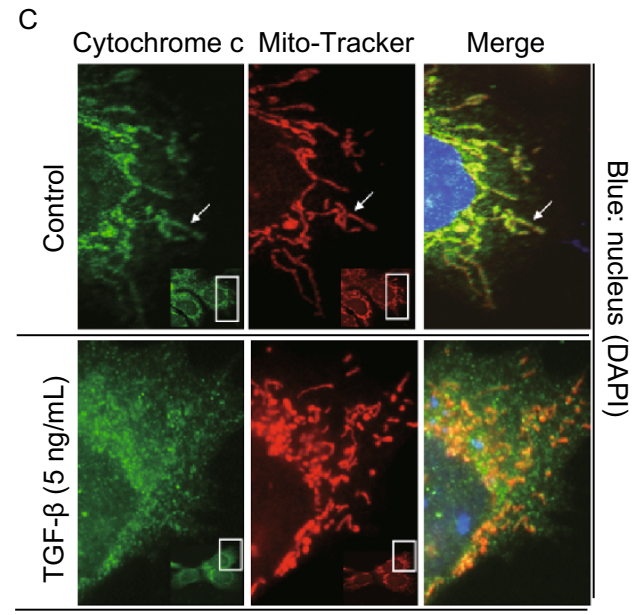

(Cytochrome c: green; mitochondria: red; magnification: 400x)

$\mathrm{H}$

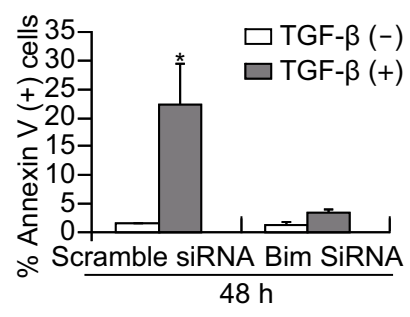

siRNA system to suppress the expression of Bim. Western blotting results indicated that Bim expression was effectively knocked down in Bim specific siRNA-transfected cells (Fig. 1G). Apoptosis assays revealed that Bim knock-down effectively protected cells against TGF- $\beta$-induced apoptosis (Fig. $1 \mathrm{G}$ and $1 \mathrm{H}$ ). These results suggest that TGF- $\beta$-induced apoptosis is Bim dependent in Hep3B cells.

\section{FoxO3 and Smad2/3 are activated and cooperate to mediate Bim up-regulation}

FoxO3 is a key transcription factor to regulate Bim gene expression (Hagenbuchner et al., 2012). In order to test the function of FoxO3 in TGF- $\beta$-induced apoptosis, cells were treated with TGF- $\beta$ and Western blotting was performed. We found that $\mathrm{FoxO} 3$ was dephosphorylated at threonine 32 (Thr32) residue after treatment with TGF- $\beta$ for $30 \mathrm{~min}$, but the other three serine 253,318 , or 321 residues were not (Fig. 2A). FoxO3 was increased after treatment with TGF- $\beta$ for $120 \mathrm{~min}$, which may be caused by dephosphroylation of p32FoxO3 (Fig. 2A). TGF- $\beta$ triggered dramatic Smad2/3 phosphorylation within $15 \mathrm{~min}$ and the protein levels of both Smad2/3 and smad4 were not apparently affected (Fig. 2A). It is well documented that activated FoxO3 could move into nucleus to regulate target gene expression. Here we observed that TGF- $\beta$-induced Smad2/3 phosphorylation activation mirrored FoxO3 Thr32 dephosphorylation activation (Fig. 2A). To assess whether FoxO3 and Smad2/3 could be activated simultaneously and cooperate to regulate target gene transcription, double immunostaining assays were performed. Our data demonstrated that TGF- $\beta$ treatment induced $\mathrm{FoxO} 3$ translocation into the nucleus in a similar time course with Smad2/3 (Fig. 2B). Co-immunoprecipitation (co-IP) experiments further confirmed that TGF- $\beta$ was able 
A

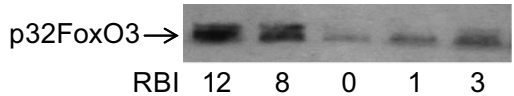

p318/321FoxO3 $\rightarrow$

$\begin{array}{llllll}\text { RBI } & 1 & 2.9 & 1.8 & 3.3 & 3.3\end{array}$

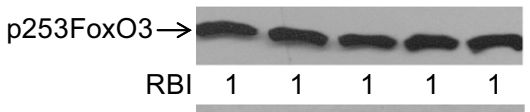

$\begin{array}{rlllll}\mathrm{FoxO} 3 \rightarrow & & & & & \\ \mathrm{RBI} & 1 & 1.6 & 2.2 & 2.3 & 1.4\end{array}$
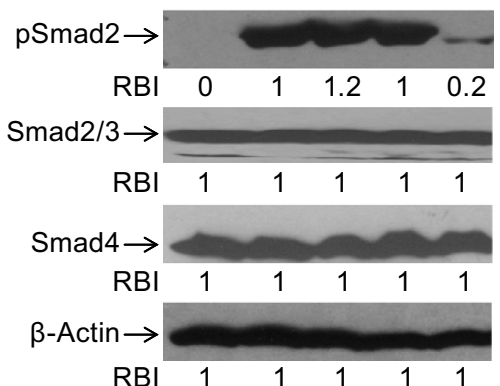

B

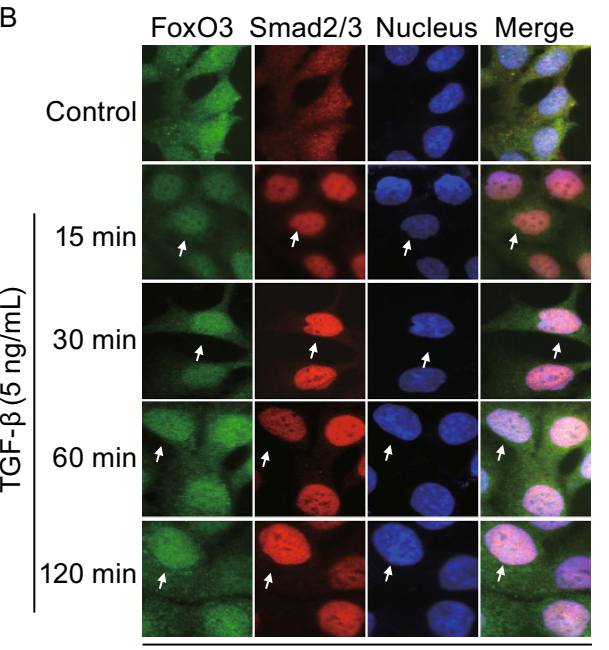

FoxO3: green (FITC);

Smad2/3: red (TRITC);

Nucleus: blue (DAPI);

Magnification: (200x)
C

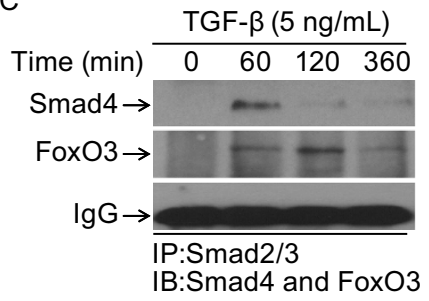

D

FoxO3-siRNA $\frac{\text { Control }}{---}-\frac{24 \mathrm{~h}}{++}$

Scramble-siRNA $-\quad++-$

TGF- $\beta(5 \mathrm{ng} / \mathrm{mL})-+-++$

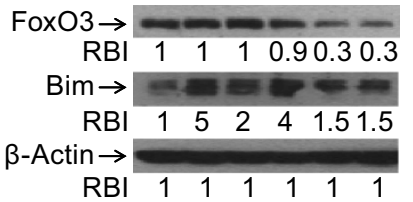

E

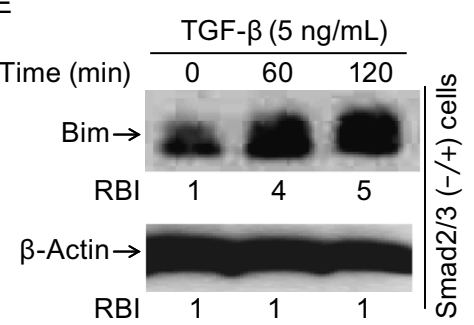

$\mathrm{F}$

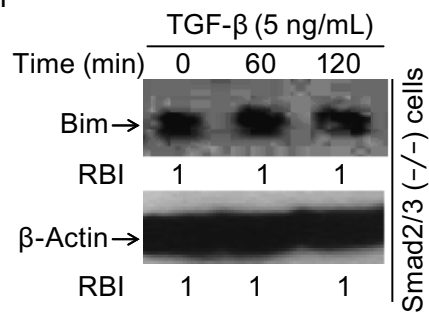

Figure 2. FoxO3 and Smad2/3 are activated and cooperate to mediate Bim up-regulation. (A) TGF- $\beta$ induces FoxO3 dephosphorylation at Thr32. Cells treated with TGF- $\beta(5 \mathrm{ng} / \mathrm{mL})$ for indicated times were harvested and cell lysates were prepared for Western blotting to examine protein levels of p32FoxO3, p253FoxO3, p318/321FoxO3, FoxO3, Smad2/3, pSmad2 and Smad4 with specific antibodies respectively. Levels of equal protein loading were determined by $\beta$-Actin. Relative band intensities (RBIs) were analyzed by the Image J software. (B) Smad2/3 and FoxO3 co-translocation to nucleus. Hep3B cells treated with TGF- $\beta$ ( $5 \mathrm{ng} / \mathrm{mL}$ ) for indicated times were fixed with paraformaldehyde and immunostained with anti-Smad2/3 or anti-FoxO3 primary antibodies. Bound Smad2/3 antibody was recognized with Cy3-conjugated donkey anti-mouse IgG (Red) and FoxO3 antibody was recognized with FITC-conjugated goat anti-rabbit IgG (Green). (C) TGF- $\beta$-induced FoxO3-Smad2/3 complex formation. Cells treated for 60,120 and $360 \mathrm{~min}$ or not were harvested and cell lysates were prepared for immunoprecipitation with anti-Smad2/3 followed by immunoblotting with anti-Smad4 mAb or anti-FoxO3 pAb. Equal protein amounts loading were determined by lgG. (D) FoxO3 knockdown blocks TGF- $\beta$-induced Bim up-regulation. Cells were transfected with FoxO3 specific interfering oligonucleotides (FoxO3-siRNA) or nonspecific oligonucleotides scramble-siRNA. After transfection for $24 \mathrm{~h}$, cells treated with TGF- $\beta$ were harvested and cell lysates were prepared for Western blotting to detect levels of $\mathrm{FoxO} 3$ and Bim with specific antibodies recognizing FoxO3 and Bim. Relative band intensities (RBIs) were analyzed by the Image $\mathrm{J}$ software. $(E)$ and $(F)$ Smads knockout abolishes TGF- $\beta$-induced Bim up-regulation. Smad2 $/ 3^{-/-}$and Smad2 $/ 3^{-/+}$MEF cells treated with TGF- $\beta(5 \mathrm{ng} / \mathrm{mL})$ were harvested and cell lysates were prepared for Western blotting to detect Bim with Bim pAb. Levels of equal protein loading were determined by $\beta$-Actin. Relative band intensities (RBIs) were analyzed by the Image $\mathrm{J}$ software. Representative bands were shown. Each experiment was conducted in triplicate and repeated twice independently.

to stimulate Smad2/3 and $\mathrm{FoxO} 3$ to form a complex (Fig. 2C). Additionally, our CHIP assays and oligonucleotide pull-down assays ascertained that Smad-FoxO3 complex could bind to bim promoter (data not shown). To verify the functional involvement of Smad2/3 and FoxO3 to TGF- $\beta$ induced Bim elevation, we used the siRNA system to suppress the expression of $\mathrm{FoxO} 3$ and found that FoxO3-siRNA effectively abrogated TGF- $\beta$-induced Bim up-regulation
(Fig. 2D). To test the roles of Smad2/3, Smad knockout $\left(\mathrm{Smad} 2 / 3^{-/-}\right)$and Smad heterozygous (Smad2/3 $\left.{ }^{-/+}\right) \mathrm{MEF}$ cells were used to evaluate TGF- $\beta$-induced Bim increase. We observed that Bim was significantly increased in Smad2/

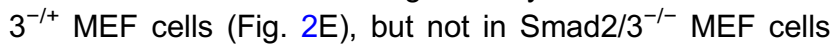
(Fig. 2F). These data suggest that both $\mathrm{FoxO} 3$ and $\mathrm{Smad} 2 / 3$ are activated and cooperate to regulate TGF- $\beta$-induced Bim up-regulation. 
A

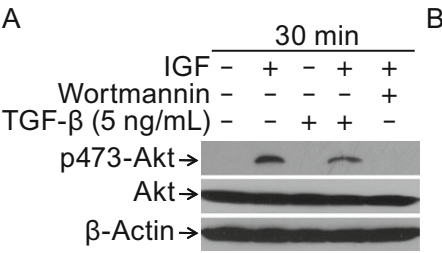

B

$$
\begin{array}{rccc}
\text { GF- } \beta(5 \mathrm{ng} / \mathrm{mL}) & - & + & + \\
\text { Wortmannin }+ & + & + \\
\text { Time }(\min ) & 0 & 15 & 30 \\
\mathrm{p} 32 \mathrm{FoxO} 3 \rightarrow & & & \\
\mathrm{RBI} & 3.6 & 1 & 1.2 \\
\text { FoxO3 } \rightarrow & & & \\
\mathrm{RBI} & 1 & 1 & 1 \\
\mathrm{Bim} \rightarrow & & & \\
\mathrm{RBI} & 1 & 1.7 & 1.7 \\
\mathrm{pSmad2} \rightarrow & & & \\
\mathrm{RBI} & 1 & 8 & 6 \\
\text { Smad2/3 } \rightarrow & & & \\
\mathrm{RBI} & 5.8 & 1 & 1.2 \\
\text { Smad4 } \rightarrow & & 1 & \\
\mathrm{RBI} & 1 & 1 & 1 \\
\beta-A c t i n \rightarrow & & & \\
\mathrm{RBI} & 1 & 1 & 1
\end{array}
$$

Figure 3. PI3K-Akt pathway is not involved in TGF- $\beta$ induced FoxO3 activation. (A) TGF- $\beta$ treatment does not induce Akt phosphorylation activation. Hep3B cells were treated with IGF-1, TGF- $\beta$, IGF-1 and TGF- $\beta$ or IGF-1 and Wortmannin for $30 \mathrm{~min}$. Cells were harvested and cell lysates were prepared for Western blotting to detect levels of p473-Akt and Akt with antibodies specifically recognizing p473-Akt and Akt. $\beta$-Actin was assessed and set up as equal protein loading control. (B) Inhibition of PI3K-Akt does not block TGF- $\beta$-induced FoxO3 activation and Bim up-regulation. Hep3B cells pretreated with Wortmannin for 30 min were stimulated with TGF- $\beta$ ( $5 \mathrm{ng} / \mathrm{mL})$ or not for 0,15 and $30 \mathrm{~min}$. Cell lysates were prepared and subjected to Western blotting to detect levels of p32FoxO3, Bim, FoxO3, pSmad2, Smad2/3, Smad4 with specific antibodies, respectively. $\beta$-Actin levels were assessed and set up as equal protein loading control. Relative band intensities (RBIs) were analyzed by the Image $\mathrm{J}$ software. Representative bands were shown. Each experiment was conducted in triplicate and repeated twice independently.

PI3K-Akt pathway is not involved in FoxO3 activation induced by TGF- $\beta$

Depending on the cell types, TGF- $\beta$ inhibits or activates Akt through changing its phosphorylation status. Previous studies has shown that Akt is involved in phosphorylation of FoxO3 at Thr32 (Higaki and Shimokado, 1999; ValderramaCarvajal et al., 2002). In our study, to verify whether FoxO3 Thr32 dephosphorylation was mediated by Akt, cells were treated or not with insulin-like growth factor 1 (IGF-1) (positive control), TGF- $\beta$, IGF-1 plus TGF- $\beta$, or IGF-1 plus Wortmannin (negative control). Our results indicated that TGF- $\beta$ did not induce Akt phosphorylation activation in Hep3B cells (Fig. 3A). To further confirm PI3K/Akt pathway was not involved in TGF- $\beta$-induced FoxO3 activation at Thr32, cells were treated with TGF- $\beta$ in the presence of Wortmannin or not. We found that TGF- $\beta$-induced dephosphorylation of FoxO3 at Thr32 and Bim up-regulation was not apparently affected (Fig. 3B). Our results also indicated that Smad2 was phosphorylated and Smad4 had no change. Notably, we found that TGF- $\beta$ and Wortmannin combination treatment led to Smad2/3 decrease, of which the underlying mechanism needs further investigation. Taken together, these data suggest that TGF- $\beta$-induced $\mathrm{FoxO} 3$ activation through dephosphorylation at Thr32 is not PI3K-Akt dependent.

\section{CKI- $\varepsilon$ regulates TGF- $\beta$-induced Bim up-regulation through FoxO3 in Hep3B cells}

CKI- $\varepsilon$ plays a ligand-dependent regulatory role in the TGF- $\beta$ signaling pathway. $\mathrm{CKI}-\varepsilon$ can repress basal activity of TGF- $\beta$-targeted molecules, while enhance TGF- $\beta$-induced Smad-mediated gene transcription (Higaki and Shimokado, 1999; Valderrama-Carvajal et al., 2002). In this study, we tested whether $\mathrm{CKI}-\varepsilon$ affects $\mathrm{FoxO} 3$ phosphorylation status. Western blotting results indicated that over-expression of wild type $\mathrm{CKI}-\varepsilon$ (WT) effectively resulted in p32FoxO3 increase (Fig. 4A), whereas over-expression of dominantnegative mutant $\mathrm{CKI}-\varepsilon$ (KD) decreased p32FoxO3 level (Fig. 4B). To assess the effects of $\mathrm{CKI}-\varepsilon$-mediated FoxO3 phosphorylation at Thr32 on TGF- $\beta$-induced Bim up-regulation, Hep3B cells harboring CKI- $\varepsilon$ (WT) or CKI- $\mathrm{C}$ (KD) plasmids were treated with TGF- $\beta$ or not. We found that TGF- $\beta$ increased Bim expression in cells expressing wild type $\mathrm{CKI}-\varepsilon$ (Fig. 4C, upper panel). TGF- $\beta$-induced Bim up-regulation was reversed in cells containing $\mathrm{CKI}-\varepsilon$ (KD) (Fig. $4 \mathrm{C}$, lower panel). We next checked the roles of endogenous CKI- $\varepsilon$ in FoxO3 Thr32 phosphorylation activation and Bim expression. Using siRNA to knock down CKI- $\varepsilon$ expression, Western blotting results showed that CKI- $\varepsilon$ knockdown effectively decreased p32FoxO3 level (Fig. 4D). More interestingly, we found that TGF- $\beta$-induced Bim up-regulation was reverted in $\mathrm{CKI}-\varepsilon$ knockdown cells (Fig. 4E), which is consistent with the results from TGF- $\beta$-treated $\mathrm{CKI}-\varepsilon$ (KD) containing cells. To further verify that Threonine 32 (Thr32) residue of FoxO3 is critical for Bim expression, FoxO3 plasmid containing a point mutation (Thr32 to Ala32: $T$ to A) was introduced to cells. After $48 \mathrm{~h}$ transfection, cells treated with TGF- $\beta$ or not. We found that over-expression of this mutant $\mathrm{FoxO} 3$ ablated TGF- $\beta$-induced Bim increase (Fig. 4F). Taken together, these data suggest that $\mathrm{CKI}-\varepsilon$ plays pivotal roles in regulating FoxO3 phosphorylation at Thr32.

\section{CKI inhibition blocks TGF- $\beta$-induced Bim increase and apoptosis}

To further evaluate the function of CKI- $\varepsilon$ in TGF- $\beta$-induced apoptosis, cells were pretreated with CKI inhibitor D4476 followed by TGF- $\beta$ incubation. Apoptosis was measured by nuclear staining and Annexin V-PI staining. We found that CKI inhibition by $\mathrm{D} 4476$ effectively protected cell against TGF- $\beta$-induced apoptosis (Fig. 5A and 5B). Immunofluoresence staining assays demonstrated that TGF- $\beta$-induced translocation of both Smad2/3 and FoxO3 was completely 
A

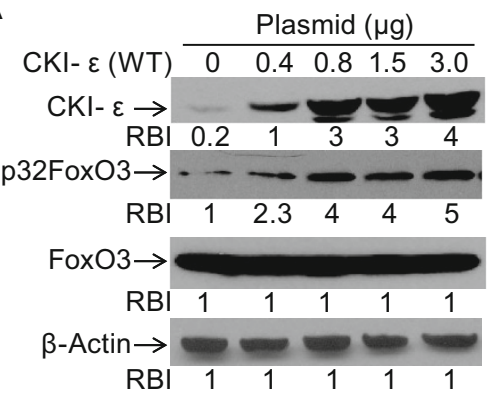

C

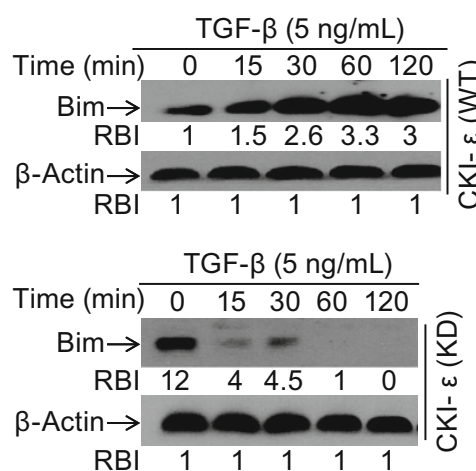

E

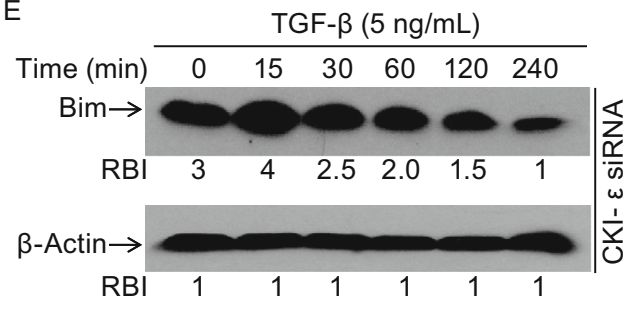

B

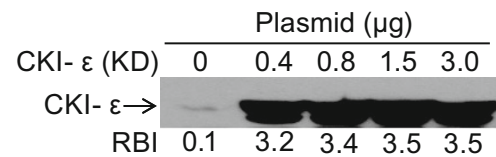

p32FoxO3 $\rightarrow$

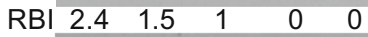

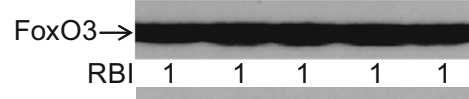

$\beta$-Actin $\rightarrow-\infty=$

D

$$
\begin{array}{rcccc} 
& \multicolumn{4}{c}{\text { Oligonucleotide }(\mathrm{nmol} / \mathrm{L})} \\
\mathrm{CKI}-\varepsilon \rightarrow & 0 & 20 & 40 & 80 \\
\mathrm{RBI} & 2.7 & 1.5 & 1 & 0
\end{array}
$$

p32FoxO3 $\rightarrow$

RBI $2 \quad 1.2 \quad 1 \quad 0$

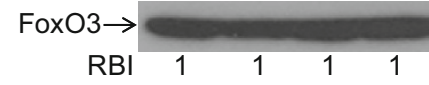

$\beta$-Actin $\rightarrow$

$\mathrm{RBI}$

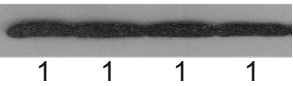

Figure 4. CKI- $\varepsilon$ regulates TGF- $\beta$-induced Bim up-regulation through FoxO3. (A) Over-expression of CKI- $\varepsilon$ (WT) induces p32FoxO3 increase. Hep3B cells were transiently transfected with different amounts of wild type CKI- $\varepsilon$ (WT) plasmids. After transfection for $48 \mathrm{~h}$, cell lysates were prepared for Western blotting to detect levels of CKI- $\varepsilon$ and p32FoxO3. Equal protein loading was determined by $\beta$-Actin. Relative band intensities (RBIs) were analyzed by the Image $\mathrm{J}$ software. (B) Mutation of CKI- $\varepsilon$ impairs its ability to phosphorylate FoxO3 at Thr32. Hep3B cells were transiently transfected with dominant negative mutant CKI- $\varepsilon(K D)$ (K to $R$ ). After transfection for $48 \mathrm{~h}$, cells were harvested and lysates were prepared for Western blotting. CKI- $\varepsilon$ and Bim expression were evaluated with specific antibodies recognizing CKI- $\varepsilon$ and Bim. $\beta$-Actin was assessed and set up as equal protein loading control. Relative band intensities (RBIs) were analyzed by the Image $J$ software. (C) Effects of CKI- $\varepsilon$ over-expression on TGF- $\beta$-induced Bim. Hep3B cells transiently transfected with either wild type CKI- $\varepsilon$ (WT) (upper panel) or dominant negative CKI- $\varepsilon$ (KD) (lower panel) plasmids were treated with TGF- $\beta$ for up to $120 \mathrm{~min}$ or not. Cells were harvested and lysates were prepared for Western blotting to assess Bim expression. Equal protein loading was determined by $\beta$-Actin. Relative band intensities (RBIs) were analyzed by the Image $\mathrm{J}$ software. (D) $\mathrm{CKI}-\varepsilon$ knockdown decreases p32FoxO3 levels. Hep3B cells were transfected with CKI- $\varepsilon$ specific siRNA or not. After transfection for $48 \mathrm{~h}$, cells were harvested and cell lysates were prepared for Western blotting to assess levels of CKI- $\varepsilon$ and p32FoxO3 with antibodies specifically recognizing $\mathrm{CKI}-\varepsilon$ and p32FoxO3. $\beta$-Actin was set up as equal protein loading control. Relative band intensities (RBIs) were analyzed by the Image $\mathrm{J}$ software. (E) CKI- $\varepsilon$ knockdown reverses TGF- $\beta$-induced Bim up-regulation. Hep3B cells were transfected with CKI- $\varepsilon$ siRNA or not. After transfection for $48 \mathrm{~h}$, cells were harvested and cell lysates were prepared for Western blotting to assess level of Bim. Equal protein loading was determined by $\beta$-Actin. Relative band intensities (RBIs) were analyzed by the Image J software. (F) FoxO3 mutation at Thr32 impairs TGF- $\beta$-induced Bim up-regulation. Hep3B cells, Hep3B cells transiently transfected with $\mathrm{CKI}-\varepsilon$ (WT) plasmids, Hep3B cells transiently transfected with FoxO3 (T to A) plasmids, or Hep3B cells transiently transfected with both $\mathrm{CKI}-\varepsilon(\mathrm{WT})$ and FoxO3 ( $\mathrm{T}$ to $\mathrm{A}$ ) plasmids were treated with TGF- $\beta$ or not for 120 min. Bim expression was monitored by Western blotting with anti-Bim pAb. $\beta$-Actin was assessed and set up as equal protein loading control. Relative band intensities (RBIs) were analyzed by the Image $\mathrm{J}$ software. Representative bands were shown. Each experiment was conducted in triplicate and repeated twice independently. 

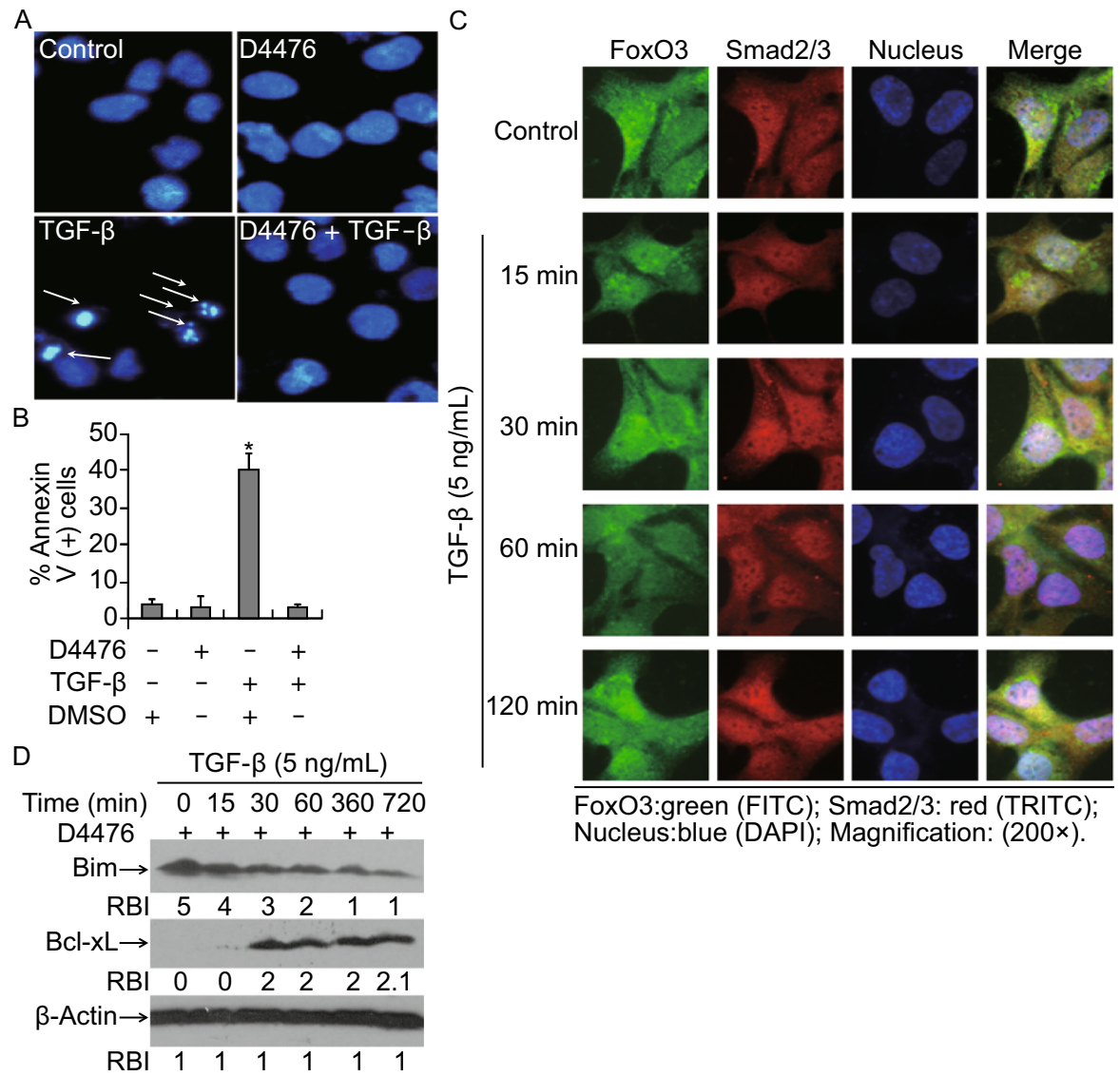
Nucleus:blue (DAPI); Magnification: (200×).

Figure 5. CKI inhibition blocks TGF- $\beta$-induced apoptosis in Hep3B cells. (A) CKI- $\varepsilon$ inhibition blocks TGF- $\beta$-induced apoptosis. Cells were treated with CKI inhibitor D4476 $(10 \mu \mathrm{mol} / \mathrm{L})$, TGF- $\beta(5 \mathrm{ng} / \mathrm{mL})$ or D4476 plus TGF- $\beta$ for $48 \mathrm{~h}$. Apoptosis was assessed by staining with Hoechst 33342 for nucleus condensation as described in 'MATERIALS AND METHODS'. A representative field of cells with the indicated treatments has been shown. Typically apoptotic cells with apoptotic nuclei were marked with white arrows. (B) Cells were treated with various conditions as indicated. Apoptosis was assessed by FACS analysis based on Annexin V-PI double staining. Statistical analysis was performed to assess the ratio of apoptosis. Data represent the mean values of three independent experiments ( ${ }^{\star} P<0.05$ ). (C) D4476 abolishes TGF- $\beta$-stimulated Smad2/3 and FoxO3 translocation. Hep3B cells grown on cover slips were pretreated with D4476 for 30 min and continuously incubated with TGF- $\beta$ ( $5 \mathrm{ng} / \mathrm{mL}$ ) or not. Immunofluorescence double staining was performed to evaluate the presence of Smad2/3 and FoxO3 with antibodies specifically recognizing Smad2/3 and FoxO3. The bound Smad2/3 primary antibody was visualized with Cy3-conjugated donkey anti-mouse IgG (Red) and FoxO3 was with FITC-conjugated goat anti-rabbit IgG (Green). Nuclei were stained with specific dye DAPI (blue). (D) D4476 blocks TGF- $\beta$-induced Bim up-regulation. Cells were pretreated with D4476 for $30 \mathrm{~min}$ followed by TGF- $\beta(5 \mathrm{ng} / \mathrm{mL})$ incubation for various times ranging from 0 to $720 \mathrm{~min}$. Cells were harvested and cell lysates were prepared for Western blotting to detect levels of Bim and Bcl-xL with specific antibodies recognizing Bim and Bcl-xL. Equal protein loading was determined by $\beta$-Actin. Relative band intensities (RBls) were analyzed by the Image J software. Representative bands were shown. Each experiment was conducted in triplicate and repeated twice independently.

blocked by D4476 (Fig. 5C). Western blotting results indicated that TGF- $\beta$-induced Bim up-regulation was reversed by this inhibitor (Fig. 5D). These data further suggest that $\mathrm{CKI}-\varepsilon$ is correlated with TGF- $\beta$-induced FoxO3 activation and Bim up-regulation.

\section{Deregulation of $\mathrm{CKI}-\varepsilon$ and p32FoxO3 in hepatocarcinoma}

It has been reported that cancer cells may have deregulated apoptosis signaling pathway (Huynh et al., 2003;
Philips and McFadden, 2004; Akagi et al., 1996). To assess whether malignant liver cells have aberrant $\mathrm{CKI}-\varepsilon$ and p32FoxO3 expression that reduces the sensitivity of cancer cells to TGF- $\beta$-induced apoptosis. Paired malignant liver tissues and adjacent non-cancer tissues from the same patients were collected. $\mathrm{CKI}-\varepsilon$ and p32FoxO3 expression was analyzed by Western blotting. Matched comparisons with adjacent normal liver tissues showed that there was consistent down-regulation of $\mathrm{CKI}-\varepsilon$ and p32FoxO3 protein expression in 2 out of 4 randomly selected malignant liver tissues (Fig. 6). These data suggest that the CKI- $\varepsilon$ activity 


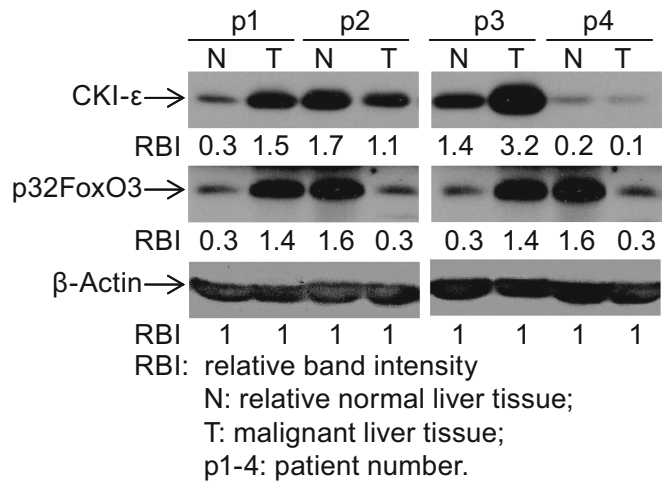

Figure 6. Deregulation of $\mathrm{CKI}-\varepsilon$ and $\mathrm{p} 32 \mathrm{FoxO} 3$ in hepatocarcinoma. Paired adjacent normal liver tissues $(\mathrm{N})$ and malignant liver tissues $(T)$ from 4 patients suffered hepatocarcinoma were collected and processed for Western blotting to detect levels of $\mathrm{CKI}-\varepsilon$ and $\mathrm{p} 32 \mathrm{FoxO} 3$ with specific antibodies recognizing $\mathrm{CKI}-\varepsilon$ and $\mathrm{p} 32 \mathrm{FoxO} 3$. Equal protein loading was determined by $\beta$-Actin. Relative band intensities (RBIs) were analyzed by the Image $\mathrm{J}$ software. $\mathrm{N}$ : samples from adjacent liver tissues; $\mathrm{T}$ : samples from malignant liver tissues; $p 1-4$ : patient number. Representative bands were shown. Each experiment was conducted in triplicate and repeated twice independently.

and phosphorylation of $\mathrm{FoxO} 3$ are deregulated in human liver cancer cells.

\section{DISCUSSION}

In this study, we have addressed the mechanism of TGF- $\beta$ induced Bim-dependent apoptosis in malignant liver cells. We found that TGF- $\beta$ induced $\mathrm{FoxO} 3$ activation by dephosphorylation at $\mathrm{Thr} 32$. Activated $\mathrm{FoxO} 3$ cooperated with $\mathrm{Smad} 2 / 3$ to mediate Bim up-regulation. $\mathrm{CKI}-\varepsilon$ regulated TGF- $\beta$-induced Bim elevation and apoptosis by affecting FoxO3 phosphorylation status at Thr32. CKI inhibition effectively blocked TGF- $\beta$-induced apoptosis. More importantly, we observed deregulation of $\mathrm{CKI}-\varepsilon$ and p32FoxO3 in liver cancer tissues. Our results delineate a CKI-FoxO/ Smad-Bim engine in which $\mathrm{Thr} 32$ of $\mathrm{FoxO} 3$ is critical for TGF- $\beta$-induced apoptosis.

Under TGF- $\beta$ stimulation, FoxO3 can bind to Runx-1 and cooperate to up-regulate Bim expression (Wildey and Howe, 2009). However, which phosphorylation site(s) of FoxO3 play(s) key roles in TGF- $\beta$-induced $\mathrm{FoxO} 3$ activation or whether FoxO3 can function as a cofactor with smad2/3 to regulate TGF- $\beta$-induced apoptosis in liver cancer cells has yet to be fully tested. In this study, we demonstrate that TGF- $\beta$ induced FoxO3 activation through specific dephosphorylation at Thr32 residue. Interestingly, the dephosphorylation activation pattern of FoxO3 was matched (mirrored) perfectly with phosphorylation activation of Smad2/3, suggesting the possibility of $\mathrm{FoxO} 3$ and Smad2/3 co-operation. We also observed that $\mathrm{FoxO} 3$ and Smad translocated to nuclear from cytoplasm simultaneously. Moreover, the following co-IP assay further confirmed that FoxO3 could be a co-factor of Smad2/3. Loss-of-function assay using siRNA-mediated FoxO3 knockdown Hep3B cells or Smad2/3 knockout MEF cells revealed that both $\mathrm{FoxO} 3$ and Smad2/3 were essential for TGF- $\beta$-induced Bim-dependent apoptosis. Therefore, these results provided profound evidence to validate the notion that TGF- $\beta$ induced FoxO3 Thr32 dephosphorylation and activated FoxO3 could cooperate with Smad2/3 to medicate Bim up-regulation.

FoxO3 dephosphorylation activation could be achieved either by phosphatases or kinases (Vogt et al., 2005). It has been reported that TGF- $\beta$ could activate PP2A, which might lead to dephosphorylation of FoxO3 (Ni et al., 2007; Tremblay and Giguere, 2008; Yan et al., 2008). However, our present data indicated that inhibition of PP2A by a specific inhibitor Okadaic Acid did not prevent TGF- $\beta$-induced FoxO3 activation (data not shown). Previous reports also showed that Akt can phosphorylate $\mathrm{FoxO} 3$ at $\mathrm{Thr} 32$ to inhibit its activity (Brunet et al., 1999; Biggs et al., 2001; Kops and Burgering, 1999). In our study, we found that TGF- $\beta$ did not induce Akt activation and Wortmannin could not affect TGF- $\beta$-stimulated FoxO3 dephosphorylation at Thr32, suggesting that PI3K/Akt was not involved in TGF- $\beta$-induced activation of FoxO3. Therefore, it would be interesting to explore the possible kinase(s) that may modulate TGF- $\beta$-induced FoxO3 activation. Our study indicated that over-expression of wild type CKI- $\varepsilon(W T)$ significantly induced $\mathrm{p} 32 \mathrm{FoxO} 3$ increase, while the dominant negative CKI- $\varepsilon(\mathrm{KD})$ over-expression caused $32 \mathrm{FoxO} 3$ decrease, suggesting that $\mathrm{CKI}-\varepsilon$ is a potential protein kinase for maintaining FoxO3 Thr32 phosphorylation. More importantly, we observed that ectopic over-expression of CKI- $\varepsilon(K D)$ result in Bim decrease in TGF- $\beta$-treated cells. Thus, we hypothesized that CKI- $\varepsilon$ may be responsible for controlling the direction of the $\mathrm{CKI}-\mathrm{FoxO} / \mathrm{Smad}-\mathrm{Bim}$ engine. Indeed, TGF- $\beta$-induced Bim up-regulation was also reversed in $\mathrm{CKI}-\varepsilon$ knockdown cells, suggesting $\mathrm{CKI}-\varepsilon$ is correlated with TGF- $\beta$-induced FoxO/Smad-mediated Bim up-regulation. Additionally, ablation of Bim up-regulation by expressing mutant FoxO3 (T32A) plasmid in cells harboring CKI- $\varepsilon$ (WT) further confirmed that both $\mathrm{CKI}-\varepsilon$ and p32FoxO3 are crucial.

Based on the above observation that CKI- $\varepsilon$ acts as a protein kinase to regulate $\mathrm{FoxO} 3$ biological activity through Thr32 residue and determines Bim expression profile, we speculate that inhibition of CKI- $\varepsilon$ may inhibit TGF- $\beta$-induced Bim increase and apoptosis. As expected, we found that TGF- $\beta$-induced apoptosis was completely blocked by CKI inhibitor D4476. Further studies revealed that D4476 incubation not only impaired FoxO3 and Smad2/3 collaborating activation, but altered TGF- $\beta$-induced Bim expression profile from increase to decrease. This is consistent with our findings that $\mathrm{CKI}-\varepsilon(\mathrm{KD})$ over-expression or $\mathrm{CKI}-\varepsilon$ knockdown revert TGF- $\beta$-induced Bim expression. Taken together, these data make it clear that $\mathrm{CKI}-\varepsilon$ is able to regulate TGF- $\beta$ induced Bim expression by affecting $\mathrm{FoxO} 3$ phosphorylation status and support the model in which TGF- $\beta$ stimulates apoptosis by trigger the $\mathrm{CKI}-\mathrm{FoxO} / \mathrm{Smad}-\mathrm{Bim}$ engine. 
In an attempt to bring our studies close to clinical analysis, we then demonstrate that, in comparison with adjacent normal liver tissues, 2 out of 4 malignant liver tissues have lower $\mathrm{CKI}-\varepsilon$ and p32FoxO3 expression. Since the tumor suppressive actions of the $\mathrm{FoxO} 3$ are well documented (Renault et al., 2011; Qi et al., 2011a, b; Karube et al., 2011), our findings imply that massive inactivation of FoxO3 by Thr32 phosphorylation may either initiate a progressive cancer-prone condition or have a pro-metastatic role to promote tumor progression in liver cancer.

In summary, our data reveal a novel CKI-FoxO/Smad-Bim engine for TGF- $\beta$-induced apoptosis and its deregulation may be related to cancer development. Identification of this engine may provide a potential new therapeutic target in the treatment of liver cancer, although it remains to be defined what happens to $\mathrm{CKI}-\varepsilon$ upon TGF- $\beta$ stimulation.

\section{MATERIALS AND METHODS}

\section{Materials and cell culture}

Primary antibodies: to Bim rabbit $\mathrm{pAb}(\mathrm{BOD})$ and $\beta$-Actin mouse $\mathrm{mAb}$ (Sigma-Aldrich); to cytochrome c mouse mAb (BD Pharmingen); to Smad2/3 mouse mAb (BD Transduction laboratories); to p-Akt (473) rabbit pAb, caspase-3 rabbit pAb, p-Smad2 mAb, p-FoxO3 (Thr32/ Ser318/321/Thr253) rabbit $\mathrm{pAb}$ and Akt rabbit pAb (Cell Signaling Technology); to Smad4 mouse mAb (B-8) and FoxO3 rabbit pAb (Santa Cruz Biotechnology). Second antibodies: FITC conjugated goat anti-rabbit IgG (Santa Cruz Biotechnology); Cy3 conjugated donkey anti-mouse IgG (Jackson ImmunoResearch Lab, INC.); Wortmannin (Upstate); IGF-1 (Insulin-like growth factor 1, IGF-1) and human TGF- $\beta$ was obtained from R\&D systems; Protein G PlusSepharose (Santa Cruz Biotechnology, INC); PI (Propidium lodide, Sigma-Aldrich); DAPI (4,6-Diamidino-2-phenyindole, DAPI) and Hoechst 33342 were from Sigma-Aldrich, Inc.; Superscript-TM II reverse Transcriptase kit (Invitrogen); Hep3B cells were cultured in minimum essential medium (MEM) supplemented with $10 \%$ fetal bovine serum, 100 units $/ \mathrm{mL}$ penicillin, and $100 \mathrm{mg} / \mathrm{mL}$ streptomycin at $37^{\circ} \mathrm{C}$ and $5 \% \mathrm{CO}_{2}$. MEF cells, Smad $2 / 3^{(-)}$MEF cells and Smad2/ $3^{(-+)}$MEF cells were kindly gifted by Dr. Xiao Yang (Chinese PLA Academy of Military Medical Sciences, Beijing, China) and were similarly cultured in Dulbecco's modified Eagle's medium with the exception of serum (15\% fetal bovine serum). CKI- $\varepsilon$ (WT and KD mutant) constructs were provided by Dr. Xiaofan Wang (Department of Pharmacology and Cancer Biology, Duke University Medical Center, Durham, North Carolina, USA). Patient tissue samples were provided by Dr. Junbo Hu at Tongji Hospital, Wuhan, China).

\section{Apoptosis assays}

Apoptosis was examined by detecting phosphatidylserine (PS) exposure on cell membrane with Annexin $V$ and dye exclusion assay as described previously (Chen et al., 2001). Cells were simultaneously stained with Annexin V-FITC (green) and PI (red). This assay discriminates between intact $\left(\mathrm{FITC}^{-} / \mathrm{PI}^{-}\right)$, early apoptotic $\left(\mathrm{FITC}^{+} / \mathrm{PI}^{-}\right)$, and later apoptotic cells $\left(\mathrm{FITC}^{+} / \mathrm{PI}^{+}\right)$. Comparative experiments were performed at the same time by bivariate flow- cytometry using a FACScan (BD) and analyzed with CellQuest software on data obtained from the cell population from which debris was gated out. Nucleus condensation or DNA fragmentation was detected to indicate apoptosis in some experiments using DAPI/ Hoechst staining. Briefly, cells were washed with PBS and stained with DAPI or directly stained with Hoechst 33342 before visualization under fluorescent microscopy. At least 200 cells from 6 random selected areas were counted in each experiment. Caspase-3 activation was determined by detecting its cleaved fragments using Western blotting. Pro-caspase-3 (37 kDa) was cleaved into $17 \mathrm{kDa}$ fragment (cleaved caspase-3) during apoptosis.

\section{Co-immunoprecipitation (co-IP)}

Two near confluent 75-mm dishes of Hep3B cells were washed three times with phosphate buffered saline (PBS), collected and lysed with $500 \mu \mathrm{L}$ ice cold lysis buffer $(50 \mathrm{mmol} / \mathrm{L}$ Hepes, $\mathrm{pH} 7.5$, $150 \mathrm{mmol} / \mathrm{L} \mathrm{NaCl}, 5 \mathrm{mmol} / \mathrm{L}$ EDTA and $1 \%$ Triton X-100) containing protease inhibitor cocktail $(10 \mu \mathrm{g} / \mathrm{mL}$ Aprotinin, $1 \mathrm{nmol} / \mathrm{L}$ PMSF and $10 \mu \mathrm{g} / \mathrm{mL}$ Leupeptin) for $30 \mathrm{~min}$ at $4^{\circ} \mathrm{C}$. Lysates were clarified by centrifugation at $15,000 \times g$ for $15 \mathrm{~min}$ and pre-cleared by incubation with protein G Plus-Sepharose for $120 \mathrm{~min}$ at $4^{\circ} \mathrm{C}$. After pre-clearing, supernatants were transferred to $1.5-\mathrm{mL}$ microfuge tubes containing anti-Smad2/3 mAb plus protein G-Sepharose. After incubation with rotating overnight at $4^{\circ} \mathrm{C}$, immunoprecipitates were washed three times with RIPA lysis buffer and subjected to Western blotting analysis with anti-FoxO3 pAb and anti-Smad4 mAb.

\section{Western blotting analysis}

Western blotting was performed according to our published method (Liao et al., 2003). Hep3B cells were harvested and lysed in lysis buffer (in mmol/L: 25 HEPES, pH 7.4, 5 EDTA, 8.0 EGTA, 1.0 $\mathrm{Na}_{3} \mathrm{VO}_{4}, 0.25 \mathrm{NaF}, 0.1$ phenylmethylsulfonyl fluoride, 1.0 dithiothreitol; and $1 \% \mathrm{NP}-40,5 \mu \mathrm{g} / \mathrm{mL}$ aprotinin, $100 \mu \mathrm{g} / \mathrm{mL}$ leupeptin, $50 \mu \mathrm{g} / \mathrm{mL}$ trypsin inhibitor). Cellular protein $(20 \mu \mathrm{g})$ was loaded and separated on sodium dodecyl sulfate polyacrylamide gel (BioRad mini gel, $6 \%-12 \%$ according to target protein molecular weight) and transferred to a nitrocellulose membrane (GibcoBRL) by the standard electric transfer protocol. The membrane was blocked at room temperature with PBS containing $0.1 \%$ Tween-20 (PBST) plus $5 \%$ non-fat milk for $120 \mathrm{~min}$, probed with antibodies overnight at $4^{\circ} \mathrm{C}$, then incubated with horseradish peroxidase-labeled second antibody (KPL Corp.) in blocking buffer for $120 \mathrm{~min}$ at room temperature. The membrane was then exposed to an enhanced chemiluminescent system and autoradiography was used to visualize immunoreactive bands.

\section{Immunofluorescence double staining}

Hep3B cells were plated onto 12-mm diameter round glass cover slips in six-well plate. Next day cells were incubated with TGF- $\beta$ $(5 \mathrm{ng} / \mathrm{mL}$ ), then washed three times with PBS and fixed with $3.7 \%$ paraformaldehyde for $15 \mathrm{~min}$ at $37^{\circ} \mathrm{C}$ (As for mitochondria staining, Mito-Tracker was added into culture medium before fixation). Fixed cells were rinsed with PBS and incubated with $50 \mathrm{mmol} / \mathrm{L} \mathrm{NH} \mathrm{NCl}_{4}$ for $10 \mathrm{~min}$ at $37^{\circ} \mathrm{C}$. Cells were rinsed in PBS, sequentially permeabilized with $0.2 \%$ Triton $\mathrm{X}-100$ on ice for $5 \mathrm{~min}$, and washed with PBS 
for $5 \mathrm{~min}$ each at room temperature. After incubation for $60 \mathrm{~min}$ in blocking buffer, cells were incubated with primary antibodies for $60 \mathrm{~min}$ at room temperature or overnight at $4^{\circ} \mathrm{C}$ (primary antibody IgG was diluted into PBS with $0.05 \%$ Triton $\mathrm{X}-100$ and $0.2 \%$ BSA). After three washes with PBS ( 5 min each), cells were incubated with the secondary antibodies for $60 \mathrm{~min}$ at room temperature: fluorescein isothiocyanate (FITC) conjugated goat anti-rabbit IgG (1:200) and Cy3 conjugated donkey anti-mouse IgG (1:200). Cells were washed three times with PBS (5 min for each wash). Cells on cover slips were mounted with slow-fade anti-fade reagent containing DAPI onto glass slides and were observed under fluorescent microscopy.

Semiquantitative reverse transcription-polymerase chain reaction (RT-PCR)

To determine the mRNA levels of the concerned genes, we isolated total RNA from cells using Trizol (Invitrogen). Reverse transcription reactions were carried out with $5 \mu \mathrm{g}$ of total RNA following the standard protocol supplied with the reverse transcriptase. The resulting CDNA was used for PCR and GAPDH was used as a loading control. The primers employed for each gene are listed below. All the reactions had a hot start of $5 \mathrm{~min}$ at $95^{\circ} \mathrm{C}$ and a final elongation step at $72^{\circ} \mathrm{C}$ for $10 \mathrm{~min}$.

GAPDH: 5'-GGTATCGTGGAAGGACTCATGAC-3' (sense) and 5'-ATGCCAGTGAGCTTCCCGTCAGC-3' (antisense); Bim: 5'-ATG GCAAAGCAACCTTCTGA-3' (sense) and 5'-TCAATGCATTCTCCA CACCA-3' (antisense); Bcl-xL: 5'-ATGTCTCAGAGCAACCGGGA GC-3' (sense) and 5'-TTTCCGACTGAAGAGTGAGCCCA-3' (antisense); Bax: 5'-ACCAAGAAGCTGAGCGAGTGTC-3' (sense) and 5'-ACAAAGATGGTCACGGTCTGCC-3' (antisense).

\section{SiRNA interfering}

SiRNA transfection was performed according to the manufacturer's instructions. Briefly, cells were plated at a density of $5 \times 10^{5}$ cells/well in 6-well plates. Cells were transfected with $80 \mathrm{nmol} / \mathrm{L}$ siRNA duplex mixture (Cell Signaling Biotechnology, Beverly, MA) for $24 \mathrm{~h}$ in the presence of lipofectamine RNAiMax (Invitrogen Inc., Carlsbad, CA). A nonspecific control siRNA (Scramble siRNA) (Cell Signaling Biotechnology, Beverly, MA) was also transfected at the same concentration as the negative control.

\section{Statistical analysis}

All experiments were performed at least 3 times, and results are reported as mean $\pm 95 \%$ confidence intervals unless otherwise stated. A $P<0.05$ was considered statistically significant.

\section{ACKNOWLEDGMENTS}

This work was supported by grants from the National Basic Research Program (973 Program) (Nos. 2007CB914800 and 2006CB910102), the National Natural Science Foundation of China (Grant Nos. 30630038 and 30400098), a project grant from Chinese Academy of Sciences (KSCX2-YW-R-02) to Q.C. We greatly appreciate the gift of CKI- $\varepsilon$ (WT and KD mutant) constructs from Dr. Xiaofan Wang (Department of Pharmacology and Cancer Biology, Duke University Medical Center, Durham, North Carolina, USA).
$X Z, Y L, D L$ and $H L$ designed, performed experiments and analyzed data; $\mathrm{XZ}, \mathrm{DH}, \mathrm{JH}, \mathrm{ZL}$ and $\mathrm{QC}$ designed experiments, analyzed data, directed the whole study and wrote the manuscript. All authors read and approved the final manuscripts.

\section{ABBREVIATIONS}

Bax, Bcl2-associated X protein; Bcl-XL, B-cell lymphoma-XL; Bim, $\mathrm{Bcl} 2$-interacting mediator of cell death; $\mathrm{CKI}-\varepsilon$, casein kinase $\mathrm{I}-\varepsilon$; DAPI, 4,6-Diamidino-2-phenyindole; FITC, fluorescein isothiocyanate; FoxO, Forkhead box protein class-O; IGF-1, Insulin-like growth factor-1; mAb, monoclonal antibody; $\mathrm{pAb}$, polyclonal antibody; PBS, phosphate buffered saline; PI, Propidium lodide; PI3K, phosphoinositide 3-kinase; siRNA, small interfering RNA; Smad, the $C$. elegans protein 'SMA' and mothers against decapentaplegic 'MAD'; TGF- $\beta$, transforming growth factor- $\beta$.

\section{COMPLIANCE WITH ETHICS GUIDELINES}

Xiangxuan Zhao, Yong Liu, Lei Du, Biyun Ni, Leya He, Junbo Hu, Dahai Zhu and Quan Chen declare that they have no competing interests.

For studies with human tissues in this article: all patients were hospitalized in Wuhan Tongji Hospital. Written informed consent was provided by all study participants. The study was approved by the Ethics Committee of Wuhan Tongji Hospital.

\section{OPEN ACCESS}

This article is distributed under the terms of the Creative Commons Attribution License which permits any use, distribution, and reproduction in any medium, provided the original author(s) and the source are credited.

\section{REFERENCES}

Akagi M, Yasui W, Akama Y, Yokozaki H, Tahara H, Haruma K, Kajiyama G, Tahara E (1996) Inhibition of cell growth by transforming growth factor $\beta 1$ is associated with $p 53$-independent induction of p21 in gastric carcinoma cells. Jpn J Cancer Res 87:377-384

Biggs WH III, Cavenee WK, Arden KC (2001) Identification and characterization of members of the FKHR (FOX O) subclass of winged-helix transcription factors in the mouse. Mamm Genome 12:416-425

Brunet A, Bonni A, Zigmond MJ, Lin MZ, Juo P, Hu LS, Anderson MJ, Arden KC, Blenis J, Greenberg ME (1999) Akt promotes cell survival by phosphorylating and inhibiting a Forkhead transcription factor. Cell 96:857-868

Chen Q, Gong B, Mahmoud-Ahmed AS, Zhou A, Hsi ED, Hussein M, Almasan A (2001) Apo2L/TRAIL and Bcl-2-related proteins regulate type I interferon-induced apoptosis in multiple myeloma. Blood 98:2183-2192

Conery AR, Cao Y, Thompson EA, Townsend CM Jr, Ko TC, Luo K (2004) Akt interacts directly with Smad3 to regulate the sensitivity to TGF- $\beta$ induced apoptosis. Nat Cell Biol 6:366-372

Derynck R, Zhang YE (2003) Smad-dependent and Smad-independent pathways in TGF- $\beta$ family signalling. Nature 425:577-584 
Engel ME, Datta PK, Moses HL (1998) RhoB is stabilized by transforming growth factor $\beta$ and antagonizes transcriptional activation. J Biol Chem 273:9921-9926

Enroth S, Andersson R, Bysani M, Wallerman O, Termen S, Tuch BB, De La Vega FM, Heldin CH, Moustakas A, Komorowski J, Wadelius $C$ (2014) Nucleosome regulatory dynamics in response to TGF- $\beta$. Nucleic Acids Res 42:6921-6934

Fish KJ, Cegielska A, Getman ME, Landes GM, Virshup DM (1995) Isolation and characterization of human casein kinase I epsilon (CKI), a novel member of the CKI gene family. J Biol Chem 270:14875-14883

Graves PR, Haas DW, Hagedorn CH, Paoli-Roach AA, Roach PJ (1993) Molecular cloning, expression, and characterization of a 49-kilodalton casein kinase I isoform from rat testis. J Biol Chem 268:6394-6401

Green DR, Reed JC (1998) Mitochondria and apoptosis. Science 281:1309-1312

Hagenbuchner J, Kuznetsov A, Hermann M, Hausott B, Obexer P, Ausserlechner MJ (2012) FOXO3-induced reactive oxygen species are regulated by BCL2L11 (Bim) and SESN3. J Cell Sci 125:1191-1203

Higaki M, Shimokado K (1999) Phosphatidylinositol 3-kinase is required for growth factor-induced amino acid uptake by vascular smooth muscle cells. Arterioscler Thromb Vasc Biol 19:2127-2132

Hua X, Liu X, Ansari DO, Lodish HF (1998) Synergistic cooperation of TFE3 and smad proteins in TGF- $\beta$-induced transcription of the plasminogen activator inhibitor-1 gene. Genes Dev 12:30843095

Huynh H, Nguyen TT, Chan E, Tran E (2003) Inhibition of ErbB-2 and ErbB-3 expression by quercetin prevents transforming growth factor alpha (TGF-alpha)- and epidermal growth factor (EGF)-induced human PC-3 prostate cancer cell proliferation. Int $\mathrm{J}$ Oncol 23:821-829

Karube K, Nakagawa M, Tsuzuki S, Takeuchi I, Honma K, Nakashima Y, Shimizu N, Ko YH, Morishima Y, Ohshima K, Nakamura S, Seto M (2011) Identification of FOXO3 and PRDM1 as tumorsuppressor gene candidates in NK-cell neoplasms by genomic and functional analyses. Blood 118:3195-3204

Kato M, Yuan H, Xu ZG, Lanting L, Li SL, Wang M, Hu MC, Reddy MA, Natarajan R (2006) Role of the Akt/FoxO3a pathway in TGF$\beta 1$-mediated mesangial cell dysfunction: a novel mechanism related to diabetic kidney disease. J Am Soc Nephrol 17:33253335

Knippschild U, Gocht A, Wolff S, Huber N, Lohler J, Stoter M (2005) The casein kinase 1 family: participation in multiple cellular processes in eukaryotes. Cell Signal 17:675-689

Kops GJ, Burgering BM (1999) Forkhead transcription factors: new insights into protein kinase B (c-akt) signaling. J Mol Med (Berl) 77:656-665

Liao XD, Tang AH, Chen Q, Jin HJ, Wu CH, Chen LY, Wang SQ (2003) Role of $\mathrm{Ca}^{2+}$ signaling in initiation of stretch-induced apoptosis in neonatal heart cells. Biochem Biophys Res Commun 310:405-411

Massague J, Weis-Garcia F (1996) Serine/threonine kinase receptors: mediators of transforming growth factor $\beta$ family signals. Cancer Surv 27:41-64
Massague J, Seoane J, Wotton D (2005) Smad transcription factors. Genes Dev 19:2783-2810

Miyazono K (2000) TGF-beta/SMAD signaling and its involvement in tumor progression. Biol Pharm Bull 23:1125-1130

Naka K, Hoshii T, Muraguchi T, Tadokoro Y, Ooshio T, Kondo Y, Nakao S, Motoyama N, Hirao A (2010) TGF- $\beta$-FOXO signalling maintains leukaemia-initiating cells in chronic myeloid leukaemia. Nature 463:676-680

Nass SJ, Li M, Amundadottir LT, Furth PA, Dickson RB (1996) Role for $\mathrm{Bcl}-\mathrm{xL}$ in the regulation of apoptosis by EGF and TGF- $\beta$ in c-myc overexpressing mammary epithelial cells. Biochem Biophys Res Commun 227:248-256

Ni YG, Wang N, Cao DJ, Sachan N, Morris DJ, Gerard RD, Kuro O, Rothermel BA, Hill JA (2007) FoxO transcription factors activate Akt and attenuate insulin signaling in heart by inhibiting protein phosphatases. Proc Natl Acad Sci U S A 104:20517-20522

Park JT, Kato M, Yuan H, Castro N, Lanting L, Wang M, Natarajan R (2013) FOG2 protein down-regulation by transforming growth factor- $\beta 1$-induced microRNA-200b/c leads to Akt kinase activation and glomerular mesangial hypertrophy related to diabetic nephropathy. J Biol Chem 288:22469-22480

Philips N, McFadden K (2004) Inhibition of transforming growth factor- $\beta$ and matrix metalloproteinases by estrogen and prolactin in breast cancer cells. Cancer Lett 206:63-68

Qi W, Weber CR, Wasland K, Roy H, Wali R, Joshi S, Savkovic SD (2011a) Tumor suppressor FOXO3 mediates signals from the EGF receptor to regulate proliferation of colonic cells. Am J Physiol Gastrointest Liver Physiol 300:G264-G272

Qi W, Weber CR, Wasland K, Savkovic SD (2011b) Genistein inhibits proliferation of colon cancer cells by attenuating a negative effect of epidermal growth factor on tumor suppressor FOXO3 activity. BMC Cancer 11:219

Ramjaun AR, Tomlinson S, Eddaoudi A, Downward J (2007) Upregulation of two $\mathrm{BH} 3-$ only proteins, $\mathrm{Bmf}$ and Bim, during TGF beta-induced apoptosis. Oncogene 26:970-981

Remy I, Montmarquette A, Michnick SW (2004) PKB/Akt modulates TGF- $\beta$ signalling through a direct interaction with Smad3. Nat Cell Biol 6:358-365

Renard E, Chadjichristos C, Kypriotou M, Beauchef G, Bordat P, Dompmartin A, Widom RL, Boumediene K, Pujol JP, Galera P (2008) Chondroitin sulphate decreases collagen synthesis in normal and scleroderma fibroblasts through a Smad-independent TGF- $\beta$ pathway-implication of C-Krox and Sp1. J Cell Mol Med 12:2836-2847

Renault VM, Thekkat PU, Hoang KL, White JL, Brady CA, Kenzelmann BD, Venturelli OS, Johnson TM, Oskoui PR, Xuan Z, Santo EE, Zhang MQ, Vogel H, Attardi LD, Brunet A (2011) The pro-longevity gene $\mathrm{FoxO} 3$ is a direct target of the p53 tumor suppressor. Oncogene 30:3207-3221

Runyan CE, Liu Z, Schnaper HW (2012) Phosphatidylinositol 3-kinase and Rab5 GTPase inversely regulate the Smad anchor for receptor activation (SARA) protein independently of transforming growth factor- $\beta$ 1. J Biol Chem 287:35815-35824

Seoane J, Le HV, Massague J (2002) Myc suppression of the p21 (Cip1) Cdk inhibitor influences the outcome of the p53 response to DNA damage. Nature 419:729-734 
Torregroza I, Evans T (2006) Tid1 is a Smad-binding protein that can modulate Smad7 activity in developing embryos. Biochem J 393:311-320

Tremblay ML, Giguere V (2008) Phosphatases at the heart of FoxO metabolic control. Cell Metab 7:101-103

Tuazon PT, Traugh JA (1991) Casein kinase I and II-multipotential serine protein kinases: structure, function, and regulation. Adv Second Messenger Phosphoprotein Res 23:123-164

Valderrama-Carvajal H, Cocolakis E, Lacerte A, Lee EH, Krystal G, Ali S, Lebrun JJ (2002) Activin/TGF- $\beta$ induce apoptosis through Smad-dependent expression of the lipid phosphatase SHIP. Nat Cell Biol 4:963-969

Vignais ML (2000) Ski and SnoN: antagonistic proteins of TGF- $\beta$ signaling. Bull Cancer 87:135-137

Vogt PK, Jiang H, Aoki M (2005) Triple layer control: phosphorylation, acetylation and ubiquitination of FOXO proteins. Cell Cycle 4:908-913
Waddell DS, Liberati NT, Guo X, Frederick JP, Wang XF (2004) Casein kinase lepsilon plays a functional role in the transforming growth factor- $\beta$ signaling pathway. J Biol Chem 279:29236-29246

Wildey GM, Howe PH (2009) Runx1 is a co-activator with FOXO3 to mediate transforming growth factor $\beta$ (TGF- $\beta$ )-induced Bim transcription in hepatic cells. J Biol Chem 284:20227-20239

Yamamura Y, Hua X, Bergelson S, Lodish HF (2000) Critical role of Smads and AP-1 complex in transforming growth factor- $\beta$ dependent apoptosis. J Biol Chem 275:36295-36302

Yan L, Lavin VA, Moser LR, Cui Q, Kanies C, Yang E (2008) PP2A regulates the pro-apoptotic activity of FOXO1. J Biol Chem 283:7411-7420 